\title{
Secondary School Students' Experiences with Reading Aloud in Uganda: A Case Study
}

\author{
Rebecca Nambi \\ School of Education, Makerere University, Uganda
}

\begin{abstract}
Reading aloud supports vocabulary build-up, provides basic background knowledge of the text and motivates learners' interest in the text even among adolescents. This paper explores classroom experiences of Senior One students (12-13 years) with reading aloud of Soyinka's (2007) play The Trials of Brother Jero. The findings show that both the teacher and the learners performed clear roles during the reading exercise and this seemed to create a systematic classroom environment for reading aloud. However data also indicates that although many of the learners declared to find value in reading aloud, some learners did not participate in the activity due to various reasons. The classroom context and the nature of the text also seemed to affect the way reading aloud was implemented during the lessons.
\end{abstract}

Index Terms — reading aloud, literature in English, learners' experiences, interaction

\section{INTRODUCTION}

Reading aloud, specifically teacher read aloud is widely identified as an advantageous classroom activity that can enhance learners' positive attitude towards reading if used effectively. Teacher read aloud can augment vocabulary build-up among learners and provide basic background knowledge of the text. Despite these benefits reading aloud is commonly associated with younger learners (Albright \& Ariail, 2005) usually giving the argument that as learners grow into adolescents and become progressively competent readers they do not need to listen to other readers (Cliff Hodges, 2011). More so, literature on the value and experiences of reading aloud broadly focuses more on teacher read aloud and less on learners' read aloud and their experiences. Studying learners' experiences of their classroom experiences in general and reading aloud in particular is a worthwhile undertaking because the learners are major participants in the reading process.

In this paper I explore how learners in one secondary school in Uganda perceived and experienced reading aloud as a classroom activity during their literacy lessons. Globally, literacy is considered to be a powerful skill that leads to personal and social development (UNESCO, 2014). Literacy proficiency among the youth in sub-Saharan countries is $70 \%$ (UNESCO, 2015) while in Uganda in particular it is $48.3 \%$ (UNEB, 2012). These figures are so low compared to other global figures of $91 \%$ (UNESCO, 2015). Studying how literacy is taught in secondary school in Uganda should be a perennial area of concern in a bid to raise literacy levels to meet international standards. Reading aloud is one of the classroom strategies that National Curriculum Development Centre (NCDC) in Uganda proposes for the Literature in English lessons (NCDC, 2008a). This paper focuses on learners in one lower secondary school class, Senior One, who were reading the play, The Trials of Brother Jero at the time of this study. In the next section of the paper I show some literature on the theoretical perspectives that inform reading aloud as an collaborative classroom activity before moving on to describe the research methodology and context. The findings follow the data analysis and the paper ends with discussions and conclusions.

\section{TheORETICAL Perspectives LeAding to READing Aloud}

Reading has been described as a social activity that requires learners to interact with texts and peers as they make meaning out of them (Moje, Overby, Tysvaer, \& Morris, 2008; Guthrie, 2008). This perspective of reading echoes Vygotsky's (1978) sociocultural theory of learning that proposes that children learn through interaction with expert peers and through the use of artefacts. Vygotsky (1978) offers that talk is a tool for social interaction that leads to cognitive development. Cognitive development is achieved through social interaction when children learn some words and signals from adults. They transfer these words or symbols to their inner speech to be used at another opportunity when faced with a similar situation or challenge (Vygotsky, 1986). Speech arises spontaneously and cannot be blocked. Thus, actions or activity and speech move together in ensuring cognitive development as Vygotsky states: "the most significant moment in the course of intellectual development, which gives birth to the purely human forms of practical and abstract intelligence, occurs when speech and practical activity, ... converge" $(1978$, p. 24). The essential role of language is to assist communication, and as children grow and continue to accumulate words through social interaction they begin to use inner speech as a tool for organisation of activities.

Vygotsky's observations above offer some implications for classroom practice. In the classroom situation, speech as a sociocultural tool that leads to cognitive development feeds into several activities such as discussions, group work, 
learners' presentations, questioning, quizzes, debates, and reading aloud. Alexander (2008) draws on Vygotsky's idea that social interaction through speech is vital in the cognitive development of a child to suggest different possibilities of using dialogic teaching. Alexander states that dialogic teaching "harnesses the power of talk to engage children, stimulate and extend their thinking, advance their learning and understanding" (2008, p. 37). Drawing on evidence from research and practice Alexander outlines the different forms in which dialogic teaching can take place in the classroom. Similarly Mercer and Littleton (2007) draw on the Vygotskian theory and classroom-based research to present how speech can assist learning and development in an interactive environment. Among other aspects they conclude that extended collaboration through exploratory dialogue contributes to learners' ability to reason, communicate and learn. Given the importance of speech in enhancing learning it is useful to examine the manner in which speech through reading aloud supports interactive literacy learning.

Wray and Lewis (2000) suggest that interactive reading, among other strategies can be done using a number of strategies such as reading aloud while learners follow in their texts. Although commonly used in primary schools, literature shows that reading aloud can offer a social approach of interacting with texts even at secondary school level (Albright \& Ariail, 2005; Chambers, 1996; Clark \& Andreasen, 2014; Cliff Hodges, 2011). Cliff Hodges (2011) argues that it is reading aloud in secondary literacy lessons offers a number of advantages such as engaging learners more deeply with the text especially when the reader uses a tone that appropriately reflects the events in the text. However some writers argue that reading aloud usually involves only the teacher or just a few learners hence rendering the rest of the class passive listeners. Clark \& Andreasen (2014) advise that it is important to use the reading aloud activity alongside other strategies in order to help learners to effectively interact with texts. Kieff (2003) offers that: "Reading aloud helps young children become readers and older children become stronger readers" (Kieff, 2003, p.2).

Kieff (2003) makes suggestions for making reading adventure groups and advises that the groups should be small consisting between 20-25 students. Kieff (2003) argues that reading aloud mainly benefits the learners as they develop a community or readers. However reading aloud can also be of benefit to the teacher (Griffin, 1992; Rasinski \& Padak, 1998; Guthrie, 2008; Richardson, 2000). Griffin (1992) writes that: "Reading aloud benefits teachers by providing them with the opportunity to evaluate learners' reading skills...by diagnosing knowledge of sound-symbol relationships and knowledge of syntactic structure, determining learners' overall comprehension, and understanding students' cognitive processing of written information" (p.785). She states that in a survey in Washington they found that teachers considered reading aloud as the strongest activity that supports the teaching of reading. Hence reading aloud does not only aim at completion of a chosen text but with appropriate planning by the teacher there are other levels or sub-skills such as vocalization, vocabulary build up and tapping into learners' imagination that can be improved.

Rounds (1992) points out that despite the advantages associated with reading aloud, it is worthwhile for practitioners to be cautious when using it as an activity. She describes her own experience as part of a large class where reading aloud was used and the lessons were "horribly boring" (Rounds, 1992, p. 788). In the context of large classes, there is a danger for learners who are not directly involved in the reading to lose motivation for the lesson. At the same time, the activity of reading aloud may not add much value to accomplished readers. Rounds (1992) questions the role of reading aloud in the reading process especially among second language learners who often learn to pronounce words they do not necessary understand. In such a case reading aloud does not lead to comprehension of the content and nor does it help learners to further their understanding of the subject content. One of the recommendations suggested by Rounds (1992) to address this challenge is for teachers to employ interactive reading approaches that emphasise vocabulary build up as well as stronger levels of comprehension. In addition, reading aloud needs to be used alongside other activities such as choral reading, silent reading, discussion, note-making and note-taking (Rasinski \& Padak, 1998; Wray and Lewis, 2000; Albright \& Ariail, 2005; Chambers, 1996; Clark \& Andreasen, 2014). The instructional implications for using reading aloud also include choosing reading content that stimulates the interest of the learners and to use other materials such as pictures to support the reading process (Richardson, 1994; Chambers, 1996; Albright \& Ariail, 2005), choosing texts that learners will not find so difficult (Rasinski \& Padak,1998; Clark \& Andreasen, 2014), involving different learners in the reading process (Rounds, 1992), involving learners in selecting texts (Kieff, 2003) and inviting guest readers (Kieff, 2003; Rasinski \& Padak, 1998). Teachers usually have the autonomy to make appropriate choices for their specific classroom contexts depending on the availability of materials and general support from the school.

\section{TEACHING READING IN SECONDARY EDUCATION IN UGANDA}

Reading in secondary schools in Uganda is largely taught under the subjects of English and Literature in English. The NCDC (2008b) integrated English language syllabus from Senior One to Senior Four designates that reading is taught on a weekly basis whereby learners are assigned short passages or stories. Reading for comprehension, enjoyment, information and improving reading speed are emphasized as the key objectives for teaching reading. The syllabus also suggests that "reading is considered the most natural starting point for an integrated lesson and the teacher needs to vary the materials to sustain the interest of the learners" (NCDC, 2008b, p. 6). English is a compulsory subject at Ordinary Level and hence all learners at this level participate in reading. Literature in English on the other hand is an optional subject but it also offers opportunity for teaching reading. The NCDC (2008a) Literature syllabus prescribes a number of texts the teacher can choose from. The texts are categorised under the general genres of literature: the 
novel/short story, poetry and drama. Teachers are also encouraged to make selections for Senior One and Two outside the prescribed syllabus. In both the English and Literature syllabus, reading aloud is one of the classroom strategies that are proposed, for example, "Loud reading of the selected texts to aid the speaking skill with attention to meaning and pronunciation" (NCDC, 2008a, p. 4).

Reading among students in lower secondary schools in Uganda has been described as poor although there are variations in proficiency between urban and rural schools with urban students performing better (Clegg, Bregman \& Ottevanger, 2008). Part of the problem is attributed to a weak reading foundation in primary education where reading is not supported with appropriate materials and instruction (Penny, Ward, Read \& Bines, 2008). In primary education students are taught using their mother tongues under the thematically organised curriculum for the first three years of formal education before they transit to English in the fourth year. Ssentanda (2014) however argues that despite the strong reasons given to support of the thematic curriculum in Uganda, it presents a number of complexities for both the teachers and learners especially in the area of teaching reading. The complexities stem from the seemingly uneven implementation process among different schools whereby aspects such as location of the school, availability of or lack instructional materials and a weak teacher training system determine the learning outcomes of reading (Ssentanda, 2014). All this culminates into a low progress in reading, which in turn affects reading in secondary school.

The current proposed review of the secondary school curriculum aims to address some of the challenges facing the teaching reading by allocating more time to English and literature in English lessons. Glegg et al. (2008) suggest that Literature in English should be made a compulsory subject at the secondary school level in order to improve learners' reading and writing skills. NCDC \& Cambridge Education (2013) argue that "effective learning of a language is integrated with appreciating the literature of the language and hence literature written in any language enriches our knowledge of that language" (p. 58). To this end they suggest that $23 \%$ of the learning time per week should be allocated to languages and their literatures in a bid to improve literacy levels.

Uganda National Examinations Board (UNEB, 2012) reported that in reading comprehension "only 38.3\% showed ability to read a passage and make conclusions based on information in the text" (p.20). These dismal figures invite attention to the classroom strategies used by the teachers in an effort to gain insight into some of the gaps and possible enabling factors that can lead to improvement in the reading proficiency levels of learners.

\section{THE STUDY}

The findings presented in this paper are part of another study that sought to explore the challenges and possibilities of using learner centred pedagogy to teach secondary school literacy in Uganda (Nambi, 2015). The purpose of that qualitative study was threefold: to examine teachers' perceptions of the use of learner centred pedagogy to teach secondary school literacy in one secondary school in Uganda; to explore the impact of the school context on the use of learner centred pedagogy to teach literacy; and to examine learners' experiences with literacy and learner centred pedagogy. Reading aloud was identified as one of the teaching strategies under learner centred pedagogy. This paper presents practices and experiences of reading aloud of a single teacher and his learners in one Senior One class. Senior One is the first class in secondary school and the average age of learners is 12-13. The study was carried out in Bakira ${ }^{1}$ Senior School (BSS), which was purposively selected because Literature in English is a compulsory subject at this school and this enlarged the area sample of the number of classes to select from. BSS is government aided and this ensured stability and availability of teachers who provided rich information in relation to the research. Six teachers and six classes were studied. All were teachers of English, Literature and General Paper each holding a bachelors' degree in education.

Interpretivist theoretical lenses were used to observe and interact with the participants and the research context in a naturalistic manner (Denscombe, 2007; Stake, 1995; Yin, 2014). The methods of data collection included interview, lesson observation and documentary evidence. The different methods of data collection were useful for triangulation purposes where information from multiple perspectives provided deep and broad understanding of the research context. Data was analysed by first organising raw data in chunks according to how it seemed to address each research question (Yin, 2014). Second, data was reduced into categories to represent key concepts that arose from the reviewed literature in relation to specific research questions before it was displayed on large visible documents (Miles, Huberman \& Saldana, 2014). This was helped to handle large sets of data in a quick and manageable way and make comparisons among the different sets. Finally discourse analysis was applied to selected pieces of data with the intention of attaining social realities reflected in the data (Gee, 2014).

Tobias, the teacher who is the focus of this paper had a teaching experience of seven years and had a teaching load of 24 lessons of 35 minutes per week. Tobias taught English, Literature in English and General Paper in different classes. For the current study he was observed teaching Literature in English in a Senior One class. His mixed ability class had a total of 130 students. He taught them Wole Soyinka's play The trials of Brother Jero (2007). Tobias was interviewed about his perceptions of using interactive teaching methods such as reading aloud, role play, and discussions during his lessons before he was observed for a period of nine weeks teaching the text in his class. After each lesson observation, I held a brief post-lesson inteview in which aspects of the lesson such as his choice of activities were discussed. In

${ }^{1}$ A pseudonym is used for the school. 
addition, a group interview was carried out with six students to gain insight into their perceptions of interactive classroom activities especially during their lessons.

The play, The Trials of Brother Jero (2007) was first published in 1964 and it has had a long presence on the Ugandan secondary school Literature in English syllabus. The play centres around three major characters, Jero, Chume and Amope. The play opens with the main character, Brother Jero on stage and in a detailed soliloquy he declares that he is a prophet of God by birth and by inclination. Despite his self-declared prophecy he acknowledges the trials he faces such as the threats from the Old Prophet (his mentor) and women who unsettle him both financially and sexually. The action on stage shows that his major current trial is his debtor, Amope a petty trader from whom he took a velvet cape that he has failed to pay for. On this particular day, Amope chooses to camp outside Jero's house until he pays the debt. Unknown to Jero, Amope is Chume's wife, Jero's most committed convert and heir apparent. As the play progresses, Jero discovers the relationship between Amope and Chume and in his position as a prophet he grants Chume permission to go get his wife, take her home and beat her (something Chume has been praying for, for a long time). The events of one day in the play reveal Jero as a false prophet who refers to his congregation as customers and prays openly to God to burn his lust for the daughters of Eve but cannot resist approaching them. Although Chume finally works out the truth about Jero at the end of the play, he (Chume) is declared mad and and Jero still manages to ensnare another unsuspecting member into his congregation.

The play has a linear plot and is only 33 pages long. Tobias' class was able to read and discuss the play within one term. The students borrowed the texts from the library at the beginning of the term and brought them to all Literature lessons. The student-book ratio was one to two or in a few cases one to three. At the beginning of the term, during the first lesson, Tobias introduced the play to the students and dictated very brief notes about the author, the setting and the themes in the play. The larger parts of the other lessons were dedicated to reading aloud of the play with different learners being selected to read as different characters. The teacher sometimes participated in the read aloud. Below I present findings about how reading aloud was carried out in the Senior one class and how learners described their experiences with this activity.

The following questions guide the current paper:

1. How does the teacher implement the reading aloud activity in a Senior One class?

2. How do the Senior One learners describe their experiences with reading aloud?

\section{FINDINGS}

Specific questions were asked about how reading aloud was used in the classroom and the roles assigned to both the teacher, the readers and the rest of the classroom. The findings indicate that despite the fact that only a few students were involved in the act of reading aloud, everyone had an opportunity to read aloud. The teacher however had a leading role since he chose the readers and often decided when to start and when to stop.

\section{Integrating reading aloud in the lessons}

Data from lesson observations showed that Tobias chose the learners to read aloud. After reviewing the previous lesson Tobias' first question was usually: "Who wants to read Jero or Chume?" The learners would then put up their hands to be selected for the different roles. Approximately between 20-30 learners would put up their hands and a close observation revealed that some learners always put up their hands while a large number almost always did not volunteer. Given that the characters in the text were few, it could be understandable that most learners did not seem to show interest in reading aloud and hence resorted to following in their texts. Further probing however showed that there were some underlying reasons why some students did not volunteer to read as can be detected from Learner A's submission below:

Learner A: Actually, the teacher does not choose randomly. He first asks the class who wants to read then whoever feels ready will put up their hand and read. Mostly the children are shy some of them do not have the interest some of them do not care.

From this learner it is clear that the floor is open to all members of the class but only a few put up their hands due to shyness as he points out. Shyness is something we explore further in the section that follows, however what is noteworthy here is the fact that the teacher readily attempts to invite everyone to read and while learners are aware of this opportunity many of them choose not to participate.

Stage directions were often read by the teacher as learners followed in their texts. During post-lesson interviews Tobias said: "I usually get involved in the reading because they find some words difficult, so I kind of give the introduction". In addition to giving the introduction, Tobias' reading usually set the tempo and atmosphere for the students because whenever he started reading everyone turned to their texts in anticipation of what was to follow. His other role was to help learners make predictions and connections within the story as the reading proceeded. In such cases he would stop the reading to ask questions that seemed to aim at drawing learners' attention to particular events. For instance, when Chume tells his wife: "Hurry. I have certain work to do when I get home and I do not want you delaying me" (Soyinka, 2007, p.24), Tobias asked the learners: "Which work is that?" The learners excitedly answered together "beating". In so doing the learners connected the current occurrence in the text to an earlier event when Jero gave Chume permission to take his wife home and beat her. The excitement for the learners seemed to hinge on the fact that Amope who has largely been portrayed as a dislikeable character was not aware that she was about to be 'punished'. 
Also, during the reading activity, Tobias took on the role of monitoring the class to ensure that all learners were on task. As a result all the learners appeared to be engrossed in the reading activity. In this way reading aloud was a supervisory tool that helped the teacher to call his class to order and have all of them on the same page.

The learners played the role of either reading aloud or following the reading in their texts if the teacher did not select them. The two or three readers at a given time often stood up as they read their parts. In a way this seemed to help them sound louder and hence project their reading to the whole class. Data from lesson observation notes describes most of the readers as "fluent, articulate and lively" or "audible, very good, and confident". Some learners were able to adjust their tones to suit their roles appropriately. For example when Chume becomes spiritually excited while praying with Jero he intones the following lines: "Help 'am God. Help 'am God. I say make you help 'am. Help 'am quick quick.... Adm help 'am. Na your son, help 'am. Help this your son... Je-e-esu, J-e-esu. Help 'am one time Je-e-e-su...Abraka, Abraka, Abraka..." (Soyinka, 2007, p. 12). The student reading this part attempts to capture Chume's jabber, which provokes laughter and a loud handclap from the rest of the class. From this performance and the learners' reaction, it can be argued that for a moment reading aloud motivated their interest in reading the text as they appreciated the reader. The rest of the class sometimes took to chorusing the one line hymns such as "I will follow Jesus" (p.16) and simple responses to prayers such as "Amen" (p. 18). These brief encounters showed that the learners were engrossed in the reading of the play but more still the choruses seemed to add to their enjoyment of reading.

Data from lesson observation also showed that some learners followed their reading with simple spontaneous actions. The spontaneous actions seemed to provoke more interest for the text among the students because they were unexpected. The readers did not leave their desks but stood up to read their roles. This is what happened when reading the following extract:

CHUME: Very true, Prophet, but...

JERO: But? But? Kneel! (pointing to the ground.) Kneel!

CHUME: (wringing his hands.) Prophet!

JERO: Kneel, sinner, kneel. Hardener of heart, harbourer of Ashtoreth, Protector of Baal, kneel, kneel.

(Chume falls on his knees.) (Soyinka, 2007, p. 14)

The readers raised their voices at his point and they followed their reading with actions of 'wringing the hands', 'pointing' and finally 'kneeling'. They immersed themselves into the text and Chume was on her (the part was read by a girl) knees as she read the lines that followed this scene. The few times that reading was followed with action the learners seemed to interact deeply with the characters they were reading about. The visual impact of Chume falling to her knees portrayed a vivid image of the kind of power that Jero seemed to hold over him in particular and other members of the congregation in general. Hence the readers channelled some of their enthusiasm to the rest of the class and could have triggered better interpretation of both Jero and Chume's characters. In this snapshot of classroom interaction with the text Tobias provided room for learners to 'speak' and 'listen' to the characters and to 'see' the characters in action. During the interview, Learner A said that: "For me I was Amope and because she was sharp I had to use a sharp voice to show that arrogant attitude". Learner A does not only invest effort into her reading but along the way she interprets the content to understand Amope's attitude before she reads to the class.

The readers' confidence and fluency could be attributed to the fact that they had borrowed and read the text before the lesson as noted by Learner B: "Sometimes you even have to read the book before everyone else in order to understand the parts well". For this reason they appeared to read using an appropriate pace because they were familiar with the story and thus they did not have to stumble over many new words. Consequently reading aloud proceeded without much interruption to explain new words until the end of a scene or of a section when the teacher asked brief questions about characters or the storyline. After brief teacher led discussions, new readers were selected to continue with the following scene or section. It can be said that $85 \%$ of the lesson time was dedicated to reading aloud with a few minutes for making a few outlines or answering brief factual questions. Tobias said the following when asked about how and when learners developed detailed notes about the book: "The learners develop their own summaries of each scene in the play during their free time. In class we have to read the book because we have to finish it". It would appear then that the reason behind reading aloud was to help learners read and complete the book together. The reading activity in this case seems to be monotonous because during some lessons notes were not dictated and the learners just listened to the readers throughout the lesson without taking part in any other activity in the lesson. Although they seemed to be keen listeners as they followed the events attentively in their own texts and they mostly gave appropriate answers to the teacher's questions, it can also be argued that the act of reading aloud cannot appeal to all learners and nor can it lead to deep understanding of the key issues in the text. Learners would benefit from brief group or pair discussions or buzzing sessions to talk about events without necessarily having to answer questions about plot or characterisation.

\section{Learners' experiences with reading aloud}

Data from lesson observations and from interviews show that learners responded variously to reading aloud. Whereas most of the learners who participated in the group interview appeared to enjoy reading aloud, it was also observable that some learners were quite reserved due to a number of underlying reasons. In this section we show learners' perceptions of reading aloud in Tobias' class.

Self-confidence. Four out of the learners who participated in the study were of the view that reading aloud helped them to become confident readers and speakers. Confidence was associated with the way they were recognized by 
fellow students and the way they used the skills in other spheres. The readers were socially recognized as 'able' or 'good' amongst their peers, which seemed to boost self-assurance as the following learners said:

Learner A: I stand out because people even congratulate me. I actually develop a certain level of confidence. Because at the end of the lesson like at break time my classmates come to me and tell me how well I read. It makes me happy. Yes you actually develop a certain level of confidence.

Learner B: Sometimes, they call us the names of the characters that we read or acted out in class. So this just makes you feel like you have actually learnt something and it actually gives you some confidence.

Learner C: Actually reading aloud gives you confidence to debate. Sometimes I ask my mom to listen to me so I practice with her.

Learner D: You just have to feel free. Build your confidence. By the time you put up your hand [to read aloud] then you can do it.

In the extracts above learners appear to attach value to the secondary benefits of reading aloud, that is, developing their speaking skills and confidence building. These benefits do not relate directly to a deeper understanding of subject content but they offer insight into learners' attitude towards reading aloud. For these particular learners there is a sense of accomplishment that is traceable to the fact that they seem to be self-motivated to read in class. For instance Learner $\mathrm{C}$ takes an extra mile to practise with his mother in order for him to become a better speaker. It follows to reason then that though the learners may read articulately in class their motivation for reading aloud may not be aligned to those of the teacher.

Vocabulary build-up. Data also revealed that some learners thought that reading aloud helped them improve their vocabulary especially when they got support from the teacher and other learners. Expectedly learners had problems reading some of the words in the text and often the teacher had to step in to either help them pronounce the words appropriately or to explain the meaning. Some of the words included: 'inclination', 'siege', 'penitent', 'ingrate', 'impersonate', 'bosoms', 'blasphemy' etc. Tobias often wrote the words on the blackboard and some learners wrote them down in their books. Also, learners were sometimes seen helping the readers by prompting them when they seemed to skip over a line or a word in the text. During group interviews learners acknowledged that the support they got from the teacher and from other learners helped them as stated by the learner below when asked about some of the benefits of reading aloud:

Learner E: The students actually help you out and correct you when you make a mistake anywhere. I mean sometimes they laugh because it is funny but eventually correct you later. The teacher also helps you and it is okay because you are building your English. And you even remember it better when the students laugh at you.

Underlying tensions. Learner E seems to look beyond the discomfort of being laughed at by other learners to focus on the more important aspect of 'building' her English. However not all learners seemed to respond in the same way because 'being laughed' can also signal that the reading environment was not always friendly and this could deter other readers. Learners were probed further for reasons why some learners did not seem ready to participate in reading aloud and they said the following:

Learner A: There are many chances for talking but there are people who can even spend the whole term without saying anything in class. Some are shy. For someone to talk you must be self -willing. The teacher even changes characters to give chance to many people.

Learner B: Mostly the children are shy some of them do not have the interest some of them do not care.

Learner C: I think they are just shy. Some of them think that by reading they would be lowering their standards, like the cool guys do not read.

Learner D: I think that some of them think that by reading in class we are just showing off. Some just fear to stand up or do not want to.

Learner E: The first time it was the whole class reading aloud like a chorus but some people were just making fun others were just sleeping, I think that is why the teacher came up with the idea of just one person reading [aloud].

Three out of four students above mention that shyness could be the reason why some students held back from reading aloud. However a close look at the statements shows that there is more to the alleged shyness. For instance some learners seem to lack the motivation to take up the stand but more still it is considered a matter of prestige not to read in class. Surprisingly, other students, like Learner D intimates, assume that reading aloud is a sign of vanity among the readers. It is clear that there are many tensions here towards reading aloud and it is not easy to find the explanations behind these attitudes. The negative effects of peer pressure in schools are well documented. Hence teachers have to take into consideration that in addition to providing opportunities for reading aloud, they may also have to study the other needs and tensions among the learners. Encouragement and creating a classroom atmosphere with simple rules where learners feel safe may go a long way in motivating more learners to participate in reading aloud.

Learning process. For some learners learning to read aloud seemed to be a learning process where they had to listen and observe other readers before they acquired the skill. Learner A said: "For me I listen to the teacher, I want to talk like him". While Learner B stated: "For me I want to speak like Sheila [local TV news anchor], Shakur [BBC] or Ryan Seacrest [American Idol]". Learner C: "For me I have developed it over time from the time I was young". Models are important for these learners. It is worth noting that their selected models range from the teacher to TV personalities. They seem to extend their reading experiences beyond the classroom to their personal contexts and this suggests that 
there is some level of connection between content and their social settings. Even for learners who were afraid, they went through the motions of presenting or reading aloud and later they seemed to be willing to withstand the bad comments because perhaps it was a requirement by the teacher as Learner D said: "When I stand in-front of the class I feel shy but I just present. But some people make me feel bad by their comments". The word 'just' suggests that this learner has no alternative but to do as required despite the unfavourable classroom environment.

Examination benefits: some learners were of the view that reading aloud was useful in helping them remember important parts of the content during examinations. Learner $\mathrm{C}$ pointed out the following when asked about the benefits of reading aloud:

Learner C: It is really helpful. Like for example in the exams, you can never forget the parts you read aloud and acted. I mean you understand the parts better than the people that are just listening. You just remember the parts you read because you get them in your head for example I can remember almost all the parts of Amope.

Indeed Learner $\mathrm{C}$ had participated in reading aloud in class. Examinations are sometimes viewed as laborious and abstract because they do not seem to relate directly to life experiences or reality. However examinations are a valid assessment tool and learners more often than not are taught to respond to examination questions rather than for life experiences. Hence for Learner $\mathrm{C}$ above it seems the act of reading aloud enhanced her performance in examinations. She internalises the spoken words and uses them in an appropriate situation. The danger here is that reading aloud may be taken to be beneficial to only school content. Nevertheless, the school context in general and the classroom in particular offered different opportunities for reading. Reading aloud was just one of the activities to support reading and not an end in itself.

\section{DisCUSSION AND CONCLUSIONS}

Reading aloud, even among older learners is important. The findings presented here are similar to literature in a number of ways. The teacher and most of his students seemed to see value such as enjoyment, vocabulary build-up and development of personal confidence from reading aloud (Albright \& Ariail, 2005; Chambers, 1996; Clark \& Andreasen, 2014; Cliff Hodges, 2011; Wray \& Lewis, 2000). The reluctance and disinterest shown among some learners is also not something that is restricted to the current study (Rounds, 1992). However the discrepancies among learners' expectations and reasons for reading aloud or not need further attention. The benefits of reading aloud for the learners seem to arise in a haphazard manner whereby each learner has a different reason for participating or not participate. There is lack of coordinated outcomes; hence it is difficult to establish whether the teacher achieved his objectives when he involved the class in reading aloud. It becomes imperative then for the teacher to be more aware of the needs of his learners by ensuring that the reading environment is supportive of even the weak or 'shy' readers. For instance it was noticeable that confident readers could easily overtake the reading activity if the other learners were not encouraged to participate.

That said, the text had very few characters and naturally it was difficult to involve many learners in reading aloud. As one learner mentioned above the teacher had abandoned chorus reading due to the challenges it posed. However reading aloud was observed to be a major activity during the lessons. It is important to balance the reading activity with other strategies such as writing, drawing, discussions, and pair work (Wray \& Lewis, 2000). This would help to involve learners in the lesson as they analyse the text 'immediately' other than putting off detailed discussion for another lesson until the whole text has been read. It is also a matter of interpretation of the curriculum; in this study reading seems to be understood in a literal sense where a book was read to its completion without involving the use of other materials and activities. The play, The Trials of Brother Jero and the words therein were the centre of focus throughout most of the lessons. Discussion of complementing materials such as articles about religious zealots would enhance understanding of the content and would greatly relate to learners' own experiences.

The contextual challenges observed in this study decidedly have a great impact on reading aloud. Any teacher needs extraordinary skills to manage a large class of young adolescents. Reading aloud involves listening to different learners' voices and as they listen to each other they are bound to get excited and sometimes become rowdy. Albright and Airail's (2005) report that the teachers in their study used reading aloud as a managerial tool to control students and keep them on the same page. Whereas that is true in this study to some extent, the teacher still had to monitor that everyone had a text, was reading and was quiet as they followed in their texts. Additionally, the large class creates relaxation among some learners when they know that someone else will take the burden of reading while at the same time it limits the reading chances for everyone. True, some learners were involved in chorus reading of songs and responses to prayers such as 'Amen', but the text, though appropriate for the class, had very few characters hence rendering the rest of the class as passive readers (Clark \& Andreasen, 2014).

Finally, the group interviews involved just a portion of the learners in Tobias' class but their awareness of the benefits of reading aloud and their collective enthusiasms for the same are inspiring aspects to support it as a classroom activity. The teacher needs to tap into this readiness and find ways of inspiring more students in the reading activity. Though they had different reasons for reading, it was clear that there was a budding community of readers within Tobias' class. Tobias on his part played important roles of modeling how to read and helping the learners to make connections between events in the text. Also the school appears to support the aim of promoting reading as stipulated by 
the NCDC syllabus by making Literature in English compulsory in the Senior One and Two classes and by providing reading materials for the learners.

\section{REFERENCES}

[1] Albright, L.K., \& Ariail, M. (2005). Tapping the potential of teacher read-alouds in middle schools. Journal of Adolescent \& Adult Literacy, 48(7), 582-591.

[2] Alexander, R.J. (2008). Towards Dialogic Teaching: Rethinking Classroom Talk. (4th ed.). Osgoodby: Dialogos.

[3] Chambers, A. (1996). The reading environment: how adults help children enjoy books. Lockwood: Thimble Press.

[4] Clark, S. K., \& Andreasen, L. (2014). Examining sixth grade students' reading attitudes and perceptions of teacher read aloud: are all students on the same page? Literacy Research and Instruction, 53(2), 162-182.

[5] Clegg, A., Bregman, J., \& Ottevanger, W. (2008). Uganda secondary education and training curriculum, assessment \& examination (CURASSE): roadmap for reform. Paris: ADEA.

[6] Cliff Hodges, G. (2011). Textual drama: The value of reading aloud. English Drama Media, Issue 19, 19-26.

[7] Denscombe, M. (2007). The good research guide: for small scale social research projects (3rd ed.). McGraw-Hill: Open University Press.

[8] Gee, J.P. (2014). How to do a discourse analysis: a toolkit (2nd ed.). New York: Routledge.

[9] Griffin, S. M. (1992). Reading Aloud: An Educator comments..." TESOL Quarterly, 26(4), 784-787.

[10] Guthrie, J. (2008) (Ed.). Engaging adolescents in reading. Thousand Oaks, CA: Corwin Press.

[11] Kieff, J. (2003). Classroom idea-sparkers: revisiting the read-aloud. Childhood Education, 80(1), 28L-28S.

[12] Mercer, N., \& Littleton, K. (2007). Dialogue and the development of children's thinking: a sociocultural approach. London: Routledge.

[13] Miles, M. B., Huberman, A. M., \& Saldana, J. (2014). Qualitative Data Analysis: a methods sourcebook (3rd ed.). London: SAGE.

[14] Moje, E., Overby, M., Tysvaer, N., \& Morris, K. (2008). The complex world of adolescent literacy: myths, motivations and mysteries. Harvard Educational Review, 78(1), 107-154.

[15] National Curriculum Development Centre (NCDC). (2008a). Literature teaching syllabus: Uganda Certificate of Education, senior 1-4. Kampala: NCDC.

[16] National Curriculum Development Centre (NCDC). (2008b). The integrated English teaching syllabus: Uganda Certificate of Education, senior 1-4. Kampala: NCDC.

[17] National Curriculum Development Centre (NCDC)., \& Cambridge Education. (2013). Lower secondary curriculum assessment and examination reform programme: situational analysis report. Cambridge: Cambridge Education.

[18] Penny A., Ward M., Read T., \& Bines H. (2008). Education sector reform: the Ugandan experience. International Journal of Educational Development, 28(3), 268-285.

[19] Rasinski, T., \& Padak, N. (1998). How elementary students referred for compensatory reading instruction perform on schoolbased measures of word recognition, fluency, and comprehension. Reading Psychology, 19(2) 185-216.

[20] Richardson, J. S. (1994). Great read-alouds for prospective teachers and secondary students. Journal of Reading, 38(2), 98-103.

[21] Richardson, J.S. (2000). Read it aloud! Using literature in the secondary content classroom. Newark, DE: International Reading Association.

[22] Rounds, P. L. (1992). Another Educator Comments. TESOL Quarterly, 26(4), 787-790.

[23] Soyinka, W. (2007). The trials of Brother Jero. Oxford: Oxford University Press. (Original work published 1964).

[24] Ssentanda, M. E. (2014). The challenges of teaching reading in Uganda: curriculum guidelines and language policy viewed from the classroom. Journal of Applied Language Studies, 8(2), 1-22.

[25] Stake, R. E. (1995). The art of case study research. London: SAGE Publications.

[26] Uganda National Examination Board (UNEB). (2012). The achievement of S.2 students in English language, mathematics and biology: NAPE report. Kampala: Government Printers.

[27] United Nations Educational, Scientific and Cultural Organization (UNESCO). (2014). Teaching and learning: achieving quality for all. Paris: UNESCO.

[28] United Nations Educational, Scientific and Cultural Organization (UNESCO). (2015). Education for all 2000-2015: achievements and challenges. Paris: UNESCO.

[29] Vygotsky, L. S. (1978). Mind in society: the development of higher psychological processes. Boston: Harvard University Press.

[30] Vygotsky, L. S. (1986). Thought and language. Cambridge, MA: MIT Press.

[31] Wray, D., \& Lewis, M. (2000). Extending literacy: learning and teaching. In M. Lewis \& D. Wray (Eds.), Literacy in the secondary school (pp. 15-28). London: David Fulton Publishers Ltd.

[32] Yin, R. (2014). Case study research: design and methods (5th ed.). London: Sage.

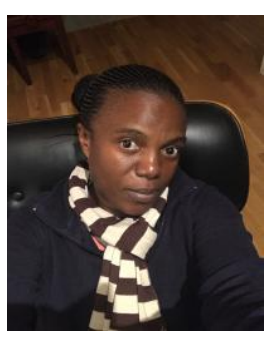

Rebecca Nambi holds a $\mathrm{PhD}$, which she obtained from the University of Cambridge in the United Kingdom in 2015. Her major areas of study include educational research methodology in general, teacher education and the teaching/learning of English and Literature. She joined the Department of Humanities and Language Education, Makerere University in 2000 as a teacher trainer and she is currently a full time Lecturer in the department. She teaches on both the graduate and undergraduate programmes and supervises and examines research students. Dr Nambi is the Unit Coordinator of English and Literature in the department and she also the Coordinator of $\mathrm{PhD}$ students in the faculty of School of Education. 